Gynecol. obstet. Invest. 1987;24:I-V

\title{
Contents, Vol. 24, 1987
}

\section{No. 1 Review}

Technical Aspects of Fetal Doppler Measurements

Ruissen, C.J.; van Vugt, J.M.G.; Hoogland, H.J.; Hoeks, A.P.G.; de Haan, J 1
Original Paper

Prospective Study of Velocity Waveforms in the Fetal Descending Thoracic and Abdominal Aorta in Fetuses Appropriate for Gestational Age and in Growth-Retarded Fetuses van Vugt, J.M.G.; Ruissen, C.J.; Hoogland, H.J.; de Haan, J 14

Prostaglandin-Induced Mid-Pregnancy Abortion Increases Plasma and Amniotic Fluid Levels of $\beta$-Lipotropin and $\beta$-Endorphin

Genazzani, A.R.; Petraglia, F.; Di Meo, G.; Santoro, V.; Facchinetti, F.; Segre, A. . . 23 Adrenergic Receptors in Inner and Outer Layers of Human Myometrium Near Term: Characterization of Beta-Adrenergic Receptor Sites by [125I]-Iodocyanopindolol Binding Breuiller, M.; Rouot, B.; Leroy, M.-J.; Blot, P.; Kaplan, L.; Ferré, F 28 Effect of Calcium and Vitamin D Supplementation on Toxaemia of Pregnancy Marya, R.K.; Rathee, S.; Manrow, M 38 Biochemical Balance in the Energy Metabolism of Fetal Organs after Perfusing the Amniotic Cavity with Oxygenated Fluorocarbon

Czekelius, P.; Paschen, W 43

Raised Acute-Phase Glycoprotein and IgM Levels in Cord Serum

Aho, K.; Palosuo, T.; Andersson, M.; Turunen, H.; Terho, P.; Vesikari, T.; Leinikki, P. 50 Lysine-Vasopressin Does Not Affect Basal and LH-RH-Stimulated LH and FSH Release during the Menstrual Cycle of Normal Women

Chiodera, P.; Volpi, R.; Cigarini, C; Caiazza, A.; Marchesi, C; Rossi, G.; Camellini, L.; Guerra, M.; Coiro, V 56

Use of Bromocriptine in the Treatment of Normoprolactinemic Infertility

Ueda, K.; Kato, H.; Fujino, T.; Nanjo, K.; Noguchi, H.; Numa, F.; Narimatsu, A.; Nakamura, Y.; Torigoe, T.; Ito, T,; Yamashita, S.; Hiratsuka, K.; Kuramoto, T.;

Tanabe, M.; Nagaya, $\mathrm{T} \quad 62$

Intrauterine Balloon Catheter for Ultrasound Evaluation of Pelvic Masses. Enhancement of Uterus Localization

Zakut, H.; Achiron, R 68

No. 2 Original Paper

Immunohistochemical Evidence for Preserved Innervation of the Human Cervix during Pregnancy

Bryman, I.; Norström, A.; Dahlström, A.; Lindblom, B 73

Ultrasonographic Assessment of Fetal Adrenal Gland and Placenta: Correlation with Estro gen in Maternal Urine

Hata, T.; Aoki, S.; Hata, K.; Takamiya, O.; Kitao, M 80

Incidence of Placental Sulfatase Deficiency on the Mode of Termination of Pregnancy 
Bedin, M.; Fournier, T.; Cabrol, D.; Bréart, G.; Kottler, M.-L.; Cedard, L 86

IV

Contents

Is the Collagen Content Reduced when the Fetal Membranes Rupture? A Clinical Study of Term and Prematurely Ruptured Membranes

Evaldson, G.R.; Larsson, B.; Jiborn, H 92

Postnatal Changes in Colloid Osmotic Pressure in Premature Infants: In Healthy Infants, in Infants with Respiratory Distress Syndrome, and in Infants Born to Mothers with Premature Rupture of Membranes

Ekblad, $\mathrm{H} \quad 95$

Lectin Receptors on Preimplantation Mouse Embryos. The Solidity of Lectin Binding

Fein, A 101

The Effect of a Single Dose of Human Chorionic Gonadotropin at Proestrus on Embryonic Mortality, Fetal Growth and Gestation Length in the Rat

Mattheij, J.A.M.; Heussen, H.; Linssen, P.C.M.L.; Swarts, J.J.M 107

Dating of the Endometrium by Microhysteroscopy (with 1 color plate)

Van Herendael, B.J.; Stevens, M.J.; Flakiewicz-Kula, A.; Hansch, Ch 114

Correlation between the Endocrine Profile of Ovulation and the Ultrasonically Detected

'Double Contour' of the Preovulatory Follicle

Jaffe, R.; Abramowicz, J.; Ben-Aderet, N 119

Parenteral and Oral Cyproterone Acetate Treatment in Severe Hirsutism

Schmidt, J.B.; Huber, J.; Spona, J 125

Effect of Ovulation of Surgically Induced Endometriosis in Rabbits

Donnez, J.; Wayembergh, M.; Casanas-Roux, F.; Karaman, Y.; Willems, T.; Ferin, J.. 131

Endometrial Carcinoma: 128 Cases at Stages I and II

Benedetti Panici, P.; Di Roberto, P.F.; Margariti, P.A.; Scambia, G.; Bompiani, A.;

Mancuso, S 138

No. 3 Original Paper

Ultrasonographic Measurement of the Human Fetal Liver in utero

Murao, F.; Takamori, H.; Aoki, S.; Hata, K.; Hata, T.; Yamamoto, K

Effects of Nifedipine on Umbilical Artery Velocity Waveforms in Healthy Human

Fetuses

Rizzo, G.; Arduini, D.; Mancuso, S.; Romanini, C 151

Amniotic Fluid $\alpha$-Fetoprotein Levels and Fetal Chromosomal Abnormalities

Barkai, G.; Katznelson, M.B.-M.; Chaki, R.; Reichman, B.; Modan, M.; Meir, E.; Serr,

D.M.; Goldman, B 155

Maternal Blood Distribution of Zinc and Copper during Labor and after Delivery

Yamashita, K.; Ohno, H.; Kondo, T.; Kawamura, M.; Mure, K.; Yorozu, Y.; Ishikawa, M.; Shimizu, T.; Taniguchi, N 161

Preeclampsia as Chronic Disseminated Intravascular Coagulation. Study of Two Parame ters: Thrombin-Antithrombin III Complex and D-Dimers

Kobayashi, T.; Terao, T 170

Puerperal Lactation, Gonadotropin Release and Estradiol Release: Effects of Metergoline and Bromocriptine

Pontiroli, A.E.; Di Micco, R.; Sartani, A.; De Pasqua, A.; Zanardi, E 179

Effect of a Beta-Adrenoceptor Antagonist, Pindolol, on Human Uterine Smooth Muscle 
Ingemarsson, I.; Adaikan, P.G.; Arulkumaran, S.; Kottegoda, S.R 185

Characterization by DEAE-Cellulose Chromatography of a Single Molecular Form of Cyclic Nucleotide Phosphodiesterase in the Myometrium of Nonpregnant Women Leroy, M.-J.; Blot, P.; Ferré, F 190

Fig. 2. EPP. The basal arteries run parallel to one another and parallel to the endometrial surface. Fig. 3. EPP. Vascularization is relatively poor. The coiled arteries form punctate and interrupted lines.

Fig. 4. LPP. Very beautiful visualization of the coiled arteries; a very specific image in the LPP. Fig. 5. ESP. Note blood vessels of two calibers on two planes, the larger underlying coiled arteries and the fine superficial network of capillaries.

Fig. 6. LSP. A fine superficial network of capillaries wrapped around the glandular openings. Note the ivory color of the endometrium, indicating stromal densification.

Fig. 7. PM phase. Note the fine superficial reticu-lar network of the capillaries and the blood pools underneath the endometrial surface.

Fig. 8. MP. Shedding of the endometrium starts near the cornua uteri. Note the already denudated fundus.

Contents V

Systemic Concentrations of Metronidazole and Its Main Metabolites after Intravenous Oral and Vaginal Administration

Fredricsson, B.; Hagström, B.; Nord, C.-E.; Rane, A200

Evaluation of the Urethral Mucosa before and after Oestrogen Treatment in Postmenopausal Women with a New Sampling Technique

Ulmsten, U.; Stormby, N 208

Radioimmunoscintigraphy Using Monoclonal Antibodies before Second-Look Surgery in Patients Suffering from Ovarian Cancer

Pateisky, N.; Philipp, K.; Sevelda, P.; Skodler, W.D.; Enzelsberger, H.; Hamilton, G.; Burchell, J.; Schatten, C 212

No. 4 Original Paper

Acupuncture before Delivery: Effect on Labor

Lyrenäs, S.; Lutsch, H.; Hetta, J.; Lindberg, B

Acute Renal Failure in Preeclampsia-Eclampsia

Stratta, P.; Canavese, C; Colla, L.; Dogliani, M.; Bussolino, F.; Bianco, O.; Gagliardi, L.; Todros, T.; Iberti, M.; Veronesi, G.V.; Bianchi, G.M 225

Cyclic Nucleotides and Suppression of Follicle-Stimulating Hormone Release by Inhibin

Simpson, W.G.; Vernon, M.W.; Maley, B.E.; Rush, M.E 232

Chromosomal Breakpoints in Aborters. Relationship with Heritable Fragile Sites

Venkatraj, V.S.; Verma, R.S 241

Nuclear Estrogen Receptors in Human Uterine Arteries

Batra, S.; Iosif, S 250

Free Testosterone and Testosterone/SHBG Index in Hirsute Women: A Comparison of

Diagnostic Accuracy

Carlström, K.; Gershagen, S.; Rannevik, G 256

Continuous, High-Dose Progestogen Treatment of Endometrial Cancer

Szarvas, Z.; Zsolnai, B.; Gimes, G.; Hidvégi, J 262

Case Reports 
Congenital Hypofibrinogenemia and Pregnancy, Obstetric and Hematological Management Gilabert, J.; Regañon, E.; Vila, V.; Baamonde, A.; Villa, P., Aznar, J.; Galbis, M. . 271 Alterations of Pathological Fetal Heart Rate Patterns in Labor following Vibroacoustic Stimulation

Ohel, G.; Simon, A.; Granat, M.; Sadovsky, E 277

Author Index 280

Subject Index 281 